\title{
High-resolution late Holocene sedimentary cores record the long history of the city of Cádiz (south-western Spain)
}

Ferréol Salomon ${ }^{1}$, Darío Bernal-Casasola ${ }^{2}$, José J. Díaz ${ }^{2}$, Macarena Lara ${ }^{2}$, Salvador Domínguez-Bella ${ }^{3}$, Damien Ertlen $^{1}$, Patrick Wassmer ${ }^{1,4}$, Pierre Adam ${ }^{5}$, Philippe Schaeffer ${ }^{5}$, Laurent Hardion ${ }^{1}$, Cécile Vittori $^{1}$, Stoil Chapkanski ${ }^{4}$, Hugo Delile ${ }^{6}$, Laurent Schmitt ${ }^{1}$, Frank Preusser ${ }^{7}$, Martine Trautmann $^{8}$, Alessia Masi ${ }^{9}$, Cristiano Vignola ${ }^{9}$, Laura Sadori ${ }^{9}$, Jacob Morales ${ }^{10}$, Paloma Vidal Matutano ${ }^{10,11}$, Vincent Robin ${ }^{12}$, Benjamin Keller ${ }^{1}$, Ángel Sanchez Bellón ${ }^{3}$, Javier Martínez López ${ }^{3}$, and Gilles Rixhon ${ }^{1,13}$

${ }^{1}$ Laboratoire Image Ville Environnement (UMR 7362), Centre National de la Recherche Scientifique (CNRS)/Université de Strasbourg, 3 rue de l'Argonne, 67000 Strasbourg, France

${ }^{2}$ Departamento de Historia, Geografía y Filosofía, Área de Arqueología, Universidad de Cádiz, Avenida Doctor Gómez Ulla 1, 11003 Cádiz, Spain

${ }^{3}$ Departamento de Ciencias de la Tierra, UGEA-PHAM, Universidad de Cádiz, Avda. República Saharahui s/n, Campus Rio San Pedro, Puerto Real, 11510 Cádiz, Spain

${ }^{4}$ Laboratoire de Géographie Physique (UMR-8591), Centre National de la Recherche Scientifique (CNRS)/

Université Paris 1, Panthéon-Sorbonne, 1 Place Aristide Briand, 92195 Meudon, France

${ }^{5}$ Institut de Chimie de Strasbourg, Biogéochimie moléculaire (UMR-7177), Centre National de la Recherche

Scientifique (CNRS)/Université de Strasbourg, 4 rue Blaise Pascal, 67000 Strasbourg, France

${ }^{6}$ Laboratoire Archéorient (UMR-5133), Centre National de la Recherche Scientifique (CNRS)/

Université de Lyon, MOM, 7 rue Raulin, 69007 Lyon, France

${ }^{7}$ Institute of Earth and Environmental Sciences - Geology, University of Freiburg,

Albertstr. 23b, 79104 Freiburg, Germany

${ }^{8}$ Laboratoire d'analyse des sols et des formations superficielles (EOST-UMS-830), Centre National de la

Recherche Scientifique (CNRS)/Université de Strasbourg, 3 rue de l'Argonne, 67000 Strasbourg, France

${ }^{9}$ Dipartimento di Biologia Ambientale, Università degli Studi "La Sapienza" di Roma,

Piazzale Aldo Moro 5, 00185 Rome, Italy

${ }^{10}$ Departamento de Ciencias Históricas, Universidad de Las Palmas de Gran Canaria, Calle Pérez del Toro, 1, Las Palmas de Gran Canaria 35003, Las Palmas, Spain

${ }^{11}$ Université Côte-d'Azur, CEPAM, CNRS, 24 Avenue des Diables Bleus, 06000 Nice, France

${ }^{12}$ Laboratoire Interdisciplinaire des environnements continentaux (UMR-7360), Centre National de la Recherche Scientifique (CNRS)/Université de Lorraine, Campus Bridoux,

Rue du Général Delestraint, 57070 Metz, France

${ }^{13}$ Ecole Nationale du Génie de l'Eau et de l'Environnement de Strasbourg (ENGEES), 1 Quai Koch, 67000 Strasbourg, France

Correspondence: Ferréol Salomon (ferreol.salomon@live-cnrs.unistra.fr)

Received: 30 October 2019 - Revised: 30 December 2019 - Accepted: 6 January 2020 - Published: 27 May 2020

Abstract. Today, coastal cities worldwide are facing major changes resulting from climate change and anthropogenic forcing, which requires adaptation and mitigation strategies to be established. In this context, sedimentological archives in many Mediterranean cities record a multi-millennial history of environmental dynamics and human adaptation, revealing a long-lasting resilience. Founded by the Phoenicians around 3000 years ago, Cádiz (south-western Spain) is a key example of a coastal resilient city. This urban centre is considered to be one of the 
first cities of western Europe and has experienced major natural hazards during its long history, such as coastal erosion, storms, and also tsunamis (like the one in $1755 \mathrm{CE}$ following the destructive Lisbon earthquake).

In the framework of an international, joint archaeological and geoarchaeological project, three cores have been drilled in a marine palaeochannel that ran through the ancient city of Cádiz. These cores reveal a $\geq 50 \mathrm{~m}$ thick Holocene sedimentary sequence. Importantly, most of the deposits date from the 1st millennium BCE to the 1st millennium CE. This exceptional sedimentary archive will allow our scientific team to achieve its research goals, which are (1) to reconstruct the palaeogeographical evolution of this specific coastal area; (2) to trace the intensity of activities of the city of Cádiz based on archaeological data, as well as geochemical and palaeoecological indicators; and (3) to identify and date high-energy event deposits such as storms and tsunamis.

\section{Introduction}

Focusing on the city of Cádiz (Figs. 1, 2, 3), this starting international, geoarchaeological project offers outstanding research perspectives for two main reasons. To begin with, Cádiz is considered to be one of the first cities of western Europe and has remained a maritime crossroads since its creation (Botto, 2014). Given its prominent position, directly northward of the Strait of Gibraltar, Cádiz has been a first-order port since its founding (Bernal Casasola, 2012). When Phoenicians originally settled, Cádiz was on the tin road between the Mediterranean and Atlantic coasts (Bendala Galán, 1988; Domínguez Monedero, 2012). Afterwards, its history was closely linked to the main Mediterranean societies developing along its shores, experiencing successive Punic (Ramírez Delgado, 1982) and Roman domination (Bernal Casasola, 2008; Lara Medina, 2016; Bernal Casasola et al., 2019a). During late antiquity, it was conquered by the Visigoths, and later by Moors in the 8th century (Fresnadillo García et al., 2008). Finally, Christians took over the city in the 13th century during the Reconquista. Whilst the city port of Cádiz was of secondary importance during the Medieval period, it regained a major role during the modern period, coinciding with the discovery of the Americas and the development of transatlantic trade (O'Flanagan, 2016).

Secondly, Cádiz was founded in a specific geographic situation off the mainland of Spain (Carayon, 2011) and provides Late Holocene high-resolution sedimentary archives located in the heart of the city. Based on topographical observations and descriptions by ancient authors, an $\mathrm{E}-\mathrm{W}$-oriented palaeochannel running through Cádiz was first identified by Ponce Cordones (1985). The topography of Cádiz reveals lowlands across the city (Fig. 2), and ancient texts mention a channel in the city (Strabo, 1923, 3, 5, 3; Pliny, 1942, 4, 119 120) (Corzo Sánchez, 1980). Two decades later, complementary geoarchaeological studies gathered geotechnical reports, and new sedimentary cores reaching a maximum depth of $9 \mathrm{~m}$ were drilled (Arteaga et al., 2001). The bedrock contact was identified at several places along the lateral borders of this palaeochannel, but this information remains unknown in its central part (Arteaga et al., 2001). More recently, it was demonstrated that this east-west palaeochannel was void of any antique archaeological remains (Lara Medina, 2018). Other hypotheses of palaeochannels running through the spit of Cádiz were also proposed, but no clear evidence is available yet (Márquez Carmona and Alonso Villalobos, 2016).

In 2018, the University of Cádiz started to rehabilitate the Valcárcel building located above the Bahía-Caleta palaeochannel. In this context, an interdisciplinary project was initiated: archaeological excavations were conducted alongside drilling of three sedimentary cores from the same area. The excavations demonstrate that La Caleta beach was a built area only from the 18th century CE (Bernal Casasola et al., 2018) and confirm the absence of structures from antiquity within the limits of the palaeochannel defined by Lara Medina (2018) (Fig. 3). The cores reveal a significant depth of at least $50 \mathrm{~m}$ along the northern side of the marine palaeochannel (Val-18/Core 3) (Fig. 4). The three cores yielded a high density of artefacts, dated from the beginning of the 1st millennium BCE to the Roman period, at depths between 15 and $40 \mathrm{~m}$ below sea level (b.s.l.) (Bernal-Casasola et al., 2020b). These archaeological findings associated with silty-clay and sand deposits highlight the existence of a deep anchorage (Bernal-Casasola et al., 2020a).

From a geological and geomorphological perspective, the palaeochannel filled by these thick sedimentary sequences points to the existence of a deep gorge in the past, probably of Pleistocene age. From a geoarchaeological perspective, the marine deposits filling this palaeochannel represent high-resolution sedimentary archives to study the evolution of the local palaeogeography and trace the urban activities of the city. Initial geochronological results via radiocarbon and thermoluminescence (TL) dating attest that at least the upper $40 \mathrm{mb}$ b.s.l. of the sequence date from the $1 \mathrm{st}$ millennium BCE and later. Whilst these sedimentary sequences represent a unique opportunity to undertake high-resolution palaeoenvironmental analyses, the associated high sedimentation rates simultaneously challenge future geomorphological reconstructions. Finally, given its location off the mainland of Spain and within a tectonically active area, storms and tsunamis could have struck the city, like in $1755 \mathrm{CE}$ right after the destructive Lisbon earthquake. Sedimentological and palaeoenvironmental evidence of high-energy events could be documented in this palaeochannel. 


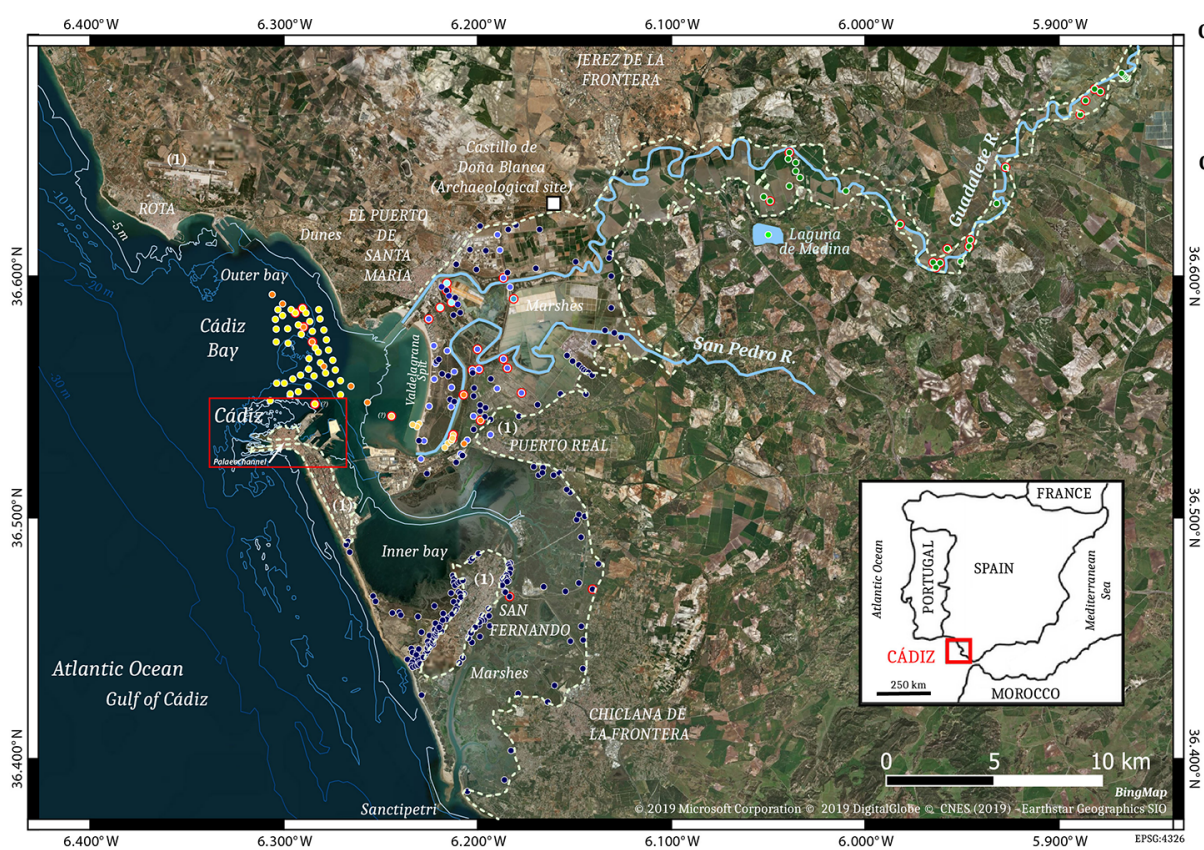

GEOLOGICAL CONTEXT

Limit of the Holocene deposits

(1) Conglomerates with oysters / "rocas ostioneras"

Late Pliocene-Early Pleistocene

GEOARCHAEOLOGICAL CORES AND TRENCHES

○ Cores/trenches with ${ }^{14} \mathrm{C}$

Lower alluvial plain of the Guadalete $R$.

- Wolf et al. (2014) $\left(33^{14} \mathrm{C}\right)$ Laguna de Medina

O Reed et al. (2001) $\left(12{ }^{14} \mathrm{C}\right)$

River mouth of the Guadalete

O Zazo et al. $(1994)\left(4{ }^{14} \mathrm{C}\right)$

O Dabrio et al. (1995) ( $\left({ }^{14} \mathrm{C}\right)$; Goy et al. $(1996)\left(2{ }^{14} \mathrm{C}\right)$

- Dabrio et al. $(1998,2000)\left(12{ }^{14} \mathrm{C}\right)$

- Luque et al. (2002) $\left(1{ }^{14} \mathrm{C}\right)$

- Arteaga \& Roos (2008) $\left(4{ }^{14} \mathrm{C}\right)$

+ Lario et al. $(1995,2002)+$ Borja Barrera et al. (1997)

t Lobo et al (2005) + Rodriguez-Polo et al (2009) (4 $\left.4^{\text {th }} \mathrm{C}\right)$

Cadiz bay - Inner bay / San Bernardino

- Arteaga \& Roos (2008) $\left(4{ }^{14} \mathrm{C}\right)$

+ Alonso Villalobos et al. (2003)

From the Valdegrana spit to the Cadiz Outer bay

○ Gutiérrez-Mas et al. (2009a) $\left(3+5{ }^{14} \mathrm{C}\right)$

O Gutiérrez-Mas et al. $(2009 \mathrm{~b})\left(3+1^{14} \mathrm{C}\right)$

O Gutiérrez-Mas $(2011)\left(3+3{ }^{14} \mathrm{C}\right)$

City of Cádiz

Study area - Figs. 2 and 3

Figure 1. Location of the study area and overview of the geological, geomorphological, and geoarchaeological researches focusing on the lower part of the Guadalete River to the Bay of Cádiz. It includes core and trench locations and radiocarbon dates available.

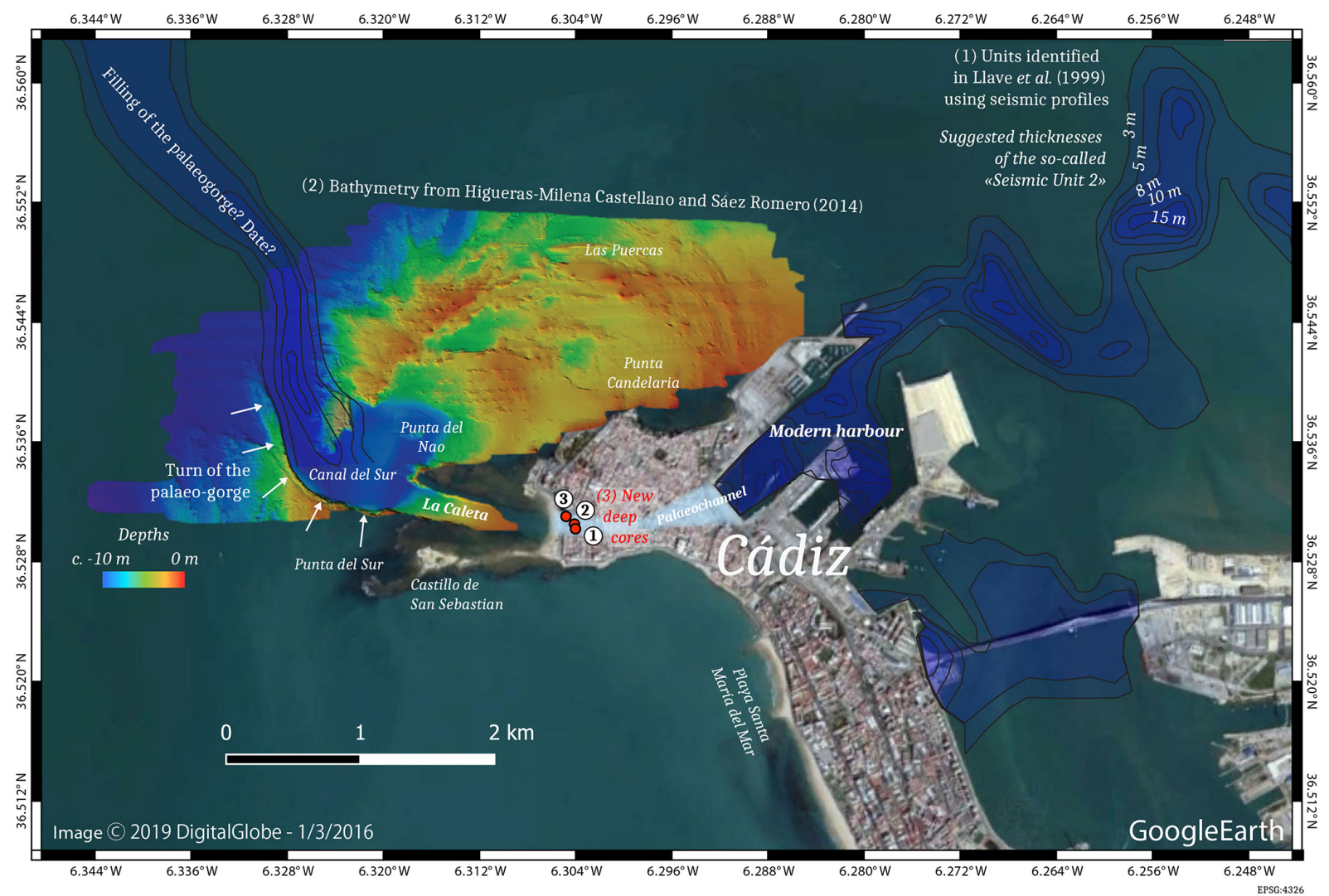

Figure 2. Palaeogorge of Cádiz - evidence from (1) seismic profiles possibly recording the filling of the palaeogorge of Cádiz (Llave et al., 1999); (2) bathymetric data showing a turn of the palaeogorge west of Cádiz (Higueras-Milena Castellano and Sáez Romero, 2014); and (3) new deep cores in Cádiz (this paper). 


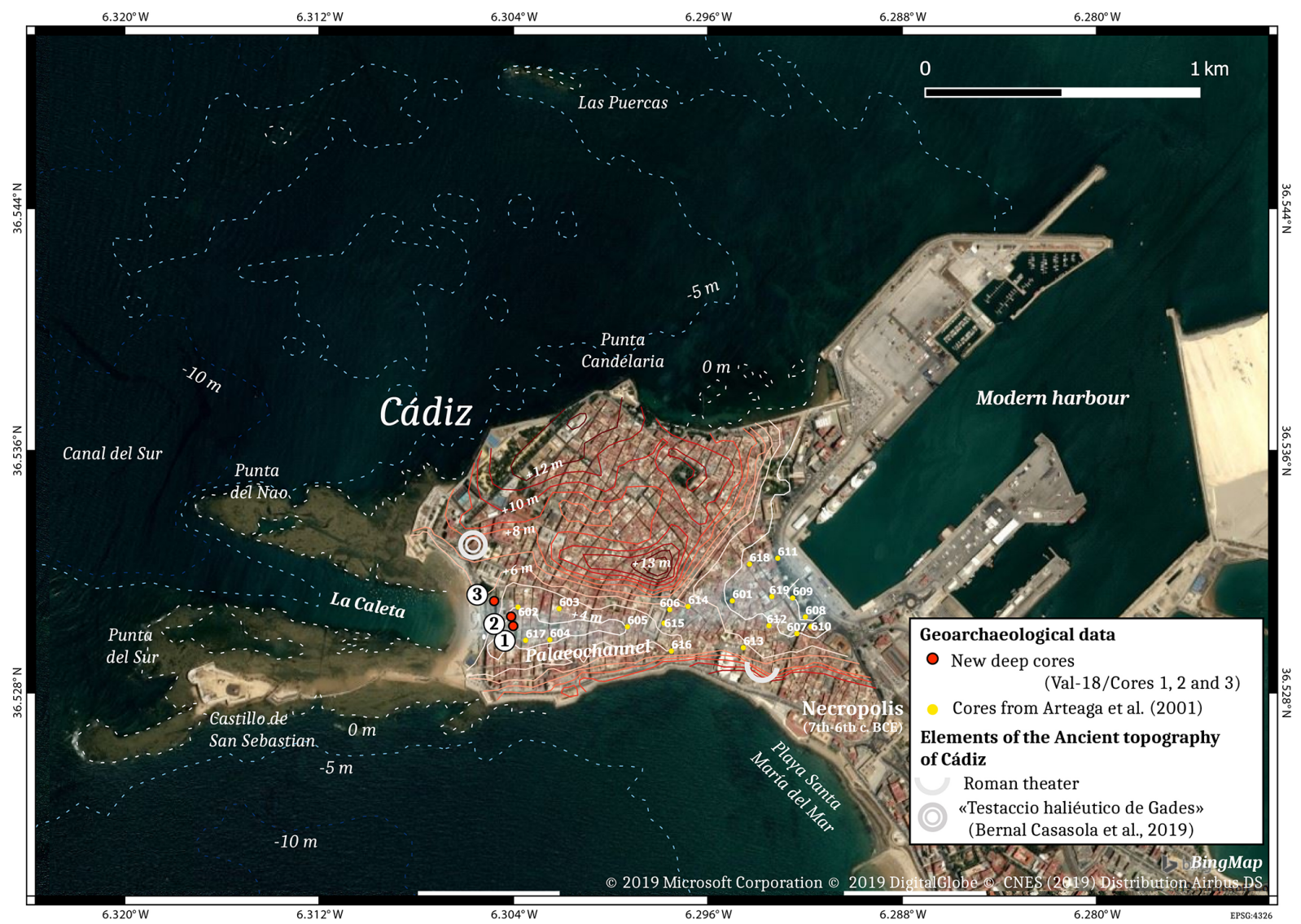

Figure 3. Locations of the three new deep cores in the context of the studied area. Bathymetric data (http://www.gpsnauticalcharts.com, last access: 11 February 2020), topographical data (collected in 1911; Ramírez Delgado, 1982), and previous cores (Arteaga et al., 2001) are reported in this figure.

This project aims to understand how this city faced coastal hazards and adapted to environmental change across its history, especially during the 1 st millennium $\mathrm{BCE}$ to the 1st millennium CE. This includes how the landscape of Cádiz appeared at the time of its foundation and how it evolved through time.

\section{Geological and geomorphological context of the Bay of Cádiz}

\subsection{Geodynamic background}

The Bay of Cádiz and its neighbouring coastal areas are affected by active Quaternary tectonics and seismicity. This is materialised by an intricate network of SW-NE and SSE-NNW-striking normal faults, sometimes prolonged by strike-slip faults (e.g. underneath the present extension of the city; Gracia et al., 2008). The low to moderate historical seismicity in this area, i.e. magnitudes between 2.5 and 4 (Gracia et al., 2008), is apparently related to the AzoresGibraltar transform fault zone and, more specifically, to $\mathrm{N}-$ $\mathrm{S}$ compressive motion in the Gibraltar area (Buforn et al.,
1988; Luque et al., 2002). In the latter, a mean uplift rate of 0.1 to $0.15 \mathrm{~mm} \mathrm{yr}^{-1}$ is suggested over the Late PleistoceneHolocene (Zazo et al., 1999). Given this geodynamic context, the whole Bay of Cádiz and coastal areas were regularly impacted by high-energy events. Offshore sediments in the bay (Gutiérrez-Mas et al., 2009a), the Valdelagrana spit bar (Luque et al., 2002), and the marshlands of the Guadalete River bay (Gutiérrez Mas, 2011) bear witness to historical tsunamis (Fig. 1).

\subsection{Coastal areas around the Bay of Cádiz}

According to the 1:50000 geological map (Baena Pérez et al., 1984), two main types of rocks or deposits constitute the coastal areas of the Bay of Cádiz. The first one, a rock formation locally known as "roca ostionera", is composed of well-compacted conglomerates and calcareous sandstones enriched in oyster shells assigned to the Late PliocenePleistocene (Llave et al., 1999; Vázquez et al., 2000) (Fig. 1). These rocks exhibit a folded structure (MacPherson, 1873; Gutiérrez Mas et al., 1991), referred to as the Cádiz anticline, 


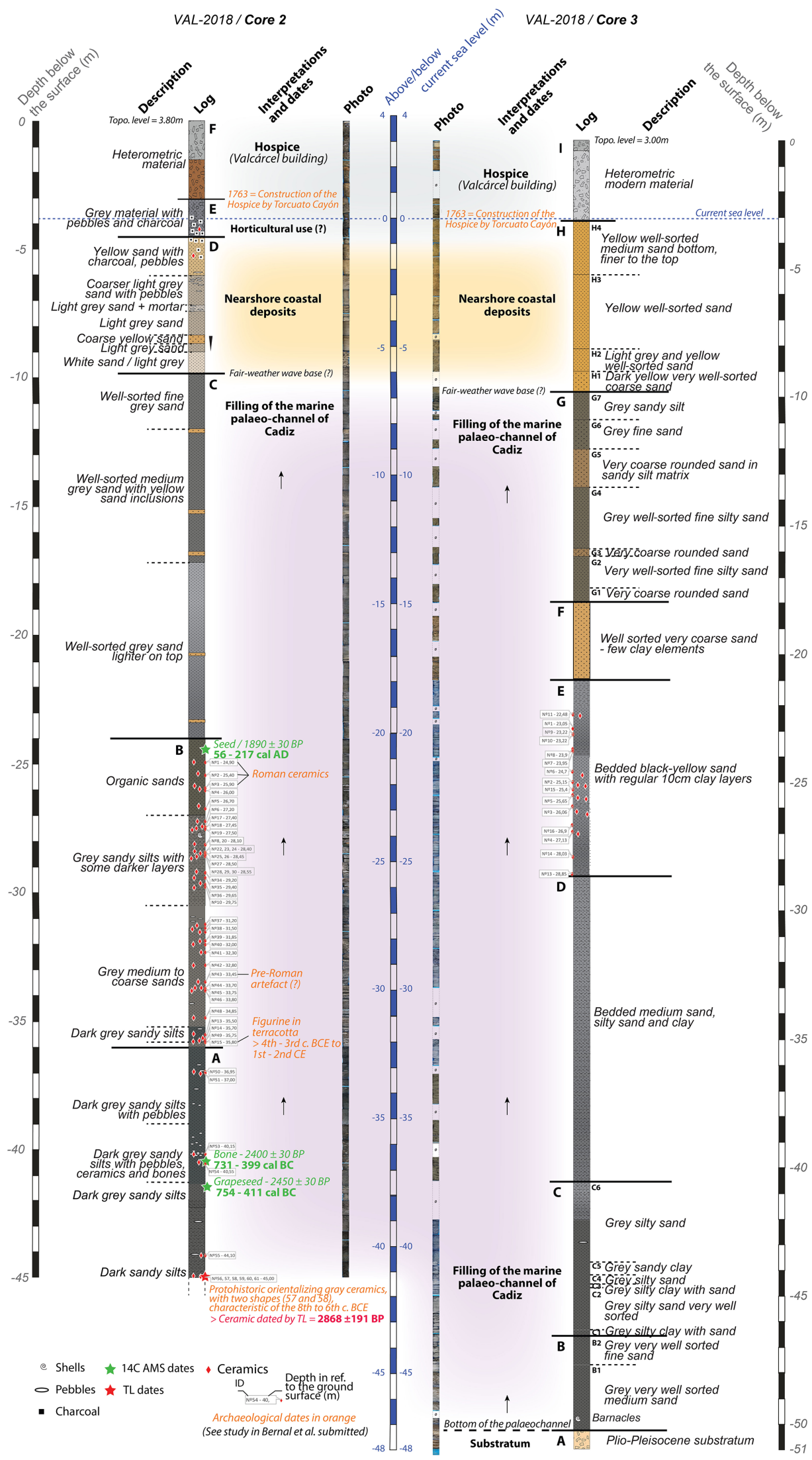

Figure 4. Stratigraphic sequences of VAL-18/Cores 1, 2, and 3 with preliminary dates (radiocarbon dates, thermoluminescence dates, and archaeological dates available from the cores under investigation - see also Bernal-Casasola et al., 2020b). 
and form the bulk of the Cádiz peninsula upon which the city lies at the northernmost tip (Domínguez-Bella, 2008).

The second types of deposits encompass Holocene sediments (Luque et al., 2002; Moral Cardona, 1994; Moral Cardona et al., 1996; Gutiérrez Mas et al., 1996) (Fig. 1). To the south, estuarine, intertidal silts and clays (marshlands or slikke) occur around the city of San Fernando (Arteaga and Roos, 2008). They are limited to the west by a sandy coastal spit. To the north, the mesotidal, N-S-oriented Valdelagrana spit-barrier system exhibits sandy beaches and beach ridges, this structure having been extensively studied over the last 3 decades (Zazo et al., 1994; Dabrio et al., 1995, 1998, 2000; Lario et al., 1995; Goy et al., 1996; Borja Barrera et al., 1997; Luque et al., 2002; Lobo et al., 2005; Arteaga and Roos, 2008; Rodríguez-Polo et al., 2009; Gutiérrez-Mas et al., 2009a, b; Gutierrez-Mas, 2011). It encloses Holocene intertidal clays and silts to the east. The lower part of the San Pedro River most probably corresponds to a palaeocourse of the Guadalete River (Dabrio et al., 1998). Finally, fringing the Cádiz peninsula, Holocene bioclastic sandy sediments delimit the "Bahía-Caleta" palaeochannel to the north and the south (Fig. 3).

\subsection{Geoarchaeological and geomorphological studies of the Guadalete River}

The paragraphs below synthesise the research conducted on the Guadalete River and towards the Bay of Cádiz since the 1990s.

\section{Fluvial dynamics in the lower reach of the Guadalete River}

Recent research mostly focused on the reconstruction of the floodplain evolution in this lower reach (Wolf et al., 2014; Wolf and Faust, 2015). In relation to the post-LGM sea-level rise, terrace formation is reported during the Late Pleistocene, with contrasting morphologies along the valley reach. The prominent sub-continuous landform upstream is buried below the Holocene floodplain deposits downstream. Holocene floodplain aggradation is recorded for the last 10000 years and enhanced phases of fluvial sedimentation are identified around 6050, 4150, 2650, and $250 \mathrm{BCE}$ and $1050 \mathrm{CE}$ (Wolf et al., 2014). The strongest sedimentation episode occurred around $1550 \mathrm{CE}$ during the Little Ice Age. Stability phases are suggested during the BøllingAllerød interstadials, prior to 6050,4150 , and $3150 \mathrm{BCE}$ and after 2350 BCE and 50 CE (Wolf et al., 2014). Highresolution analysis of lake sediments from the neighbouring Laguna de Medina reveals an aridification during the Late Holocene (Reed et al., 2001). Whilst local palaeoenvironmental studies suggest important wine production already existing in the 8th-7th centuries BCE at Castillo de Doña Blanca (Chamorro, 1994; Buxó, 2008; Iriarte-Chiapusso et al., 2017), a generalised human impact seems more difficult to infer along this river reach (Wolf et al., 2014).

\section{Evolution of the Guadalete River mouth}

Concomitant to a decelerated sea-level rise, progradation at the mouth of the Guadalete River began in the middle of the 5th millennium BCE. Goy et al. (1996) identified two periods of progradation: between 4500 and $1050 \mathrm{BCE}$ with a gap around $2050 \mathrm{BCE}$ and from $800 \mathrm{BCE}$ to the present with a gap between 750 and $900 \mathrm{CE}$. The formation of the Valdelagrana spit likely started in the 2nd millennium BCE (1850-1650 BCE) based on archaeological dates (in Gómez Ponce et al., 1997) and radiocarbon dates (in Dabrio et al., 2000), accelerated around $450 \mathrm{BCE}$ (radiocarbon dates in Zazo et al., 1996), and reduced during 50-150 CE (based on archaeological and radiocarbon dates in Gómez Ponce et al., 1997). High sedimentation recorded during the Little Ice Age (Dabrio et al., 2000; Lario et al., 1995) was related to strong human impact as well as land-use changes (Dabrio et al., 2000). The formation of the Valdelagrana spit is likely to have affected the sedimentation of the delta front and to have contributed to the sedimentation in the palaeochannel of Cádiz (Gracia and Benavente, 2000).

\section{Methodology}

Three new sedimentary sequences were extracted from the area of the Valcárcel building in Cádiz: Val-18/Core 1 $\left(36^{\circ} 31^{\prime} 48.73^{\prime \prime} \mathrm{N}, \quad 6^{\circ} 18^{\prime} 14.45^{\prime \prime} \mathrm{W} ; \quad 3.78 \mathrm{~m}\right.$ a.s.l. $)$, Val$18 /$ Core $2\left(36^{\circ} 31^{\prime} 49.85^{\prime \prime} \mathrm{N}, 6^{\circ} 18^{\prime} 14.75^{\prime \prime} \mathrm{W} ; 3.80 \mathrm{~m}\right.$ a.s.l.), and Val-18/Core $3 \quad\left(36^{\circ} 31^{\prime} 51.70^{\prime \prime} \mathrm{N}, 6^{\circ} 18^{\prime} 17.27^{\prime \prime} \mathrm{W}\right.$; $3.00 \mathrm{~m}$ a.s.l.) (Figs. 2, 3, and 4).

These cores were retrieved by the Concadiz company using a rotary drilling device between August and October 2018. The cores have a diameter of $10 \mathrm{~cm}$. Val-18/Core 1 was drilled down to $31.50 \mathrm{~m}$, Val-18/Core 2 to $45.00 \mathrm{~m}$, and Val$18 /$ Core 3 to $50 \mathrm{~m}$. Only Val-18/Core 3 reached the substratum. Val-18/Core 1 is not described in this paper since the stratigraphy is shorter and similar to Val-18/Core 2. These drillings are due to a great opportunity. It is generally very difficult to drill in a dense urban area. However, due to the renovation of the Valcárcel building by the University of Cádiz, an archaeological assessment was undertaken (Lara Medina et al., 2020). The sedimentary cores were drilled on that occasion.

Visual recognition of sedimentary units and core description was completed quickly after extraction and followed by sampling. The first samples extracted were reserved for optically stimulated luminescence (OSL) datings. OSL samples were chosen from the best preserved sections within the stratigraphic sequence. Archaeological material was extracted during the sampling and analysed by specialists (see Bernal-Casasola et al., 2020a, b). The analysis of the archaeological artefacts presented a preliminary chronologi- 
cal framework. The absolute datings were implemented on Val-18/Core 2. Radiocarbon dates were performed by Beta Analytics on seeds and bones, and a ceramic was dated by the thermoluminescence technique by the Dating and Radiochemistry Laboratory of the Universidad Autónoma of Madrid (Table 1).

\section{New sedimentary sequences from the city centre of Cádiz}

Figure 4 displays the combined stratigraphy of VAL18/Core 2 and VAL-18/Core 3, respectively drilled in the central and northern parts of the palaeochannel. Because VAL-18/Core 2 exhibits the highest concentration of artefacts, it was first targeted for numerical dating (radiocarbon and TL). VAL-18/Core 3 reached the Plio-Pleistocene substratum. Detailed analysis of the artefacts is available in Bernal-Casasola et al. (2020a, b).

\subsection{Val-18/Core-2}

This core reaches a depth of $41.20 \mathrm{~m}$ b.s.l. The bottom Unit A is at least $9 \mathrm{~m}$ thick ( 41.20 to $32.20 \mathrm{~m}$ b.s.l.) since the bedrock was not attained. It is composed of dark grey sandy silts with some pebbles. A fragment of ceramic found at the bottom of the unit is dated by TL at $850 \pm 191 \mathrm{BCE}$ (Table 1). Additionally, radiocarbon dates of a grape seed $(41.57 \mathrm{~m}$ b.s.l.) and a bone fragment $(40.85 \mathrm{~m}$ b.s.l.) respectively yield similar ages of 755-410 BCE ( $2450 \pm 30 \mathrm{BP})$ and 730-400 BCE $(2400 \pm 30 \mathrm{BP})$ (Table 1). The consistent dating results indicate that Unit A was deposited in the first part of the 1st millennium BCE.

Unit B (32.20 to $20.20 \mathrm{~m}$ b.s.1.) is composed of grey sandy silts and coarse sands. Additionally, several silty-clay layers are intercalated at depths between 23.00 and $20.20 \mathrm{~m}$ b.s.1. This unit is characterised by a high content of artefacts and ecofacts. At the bottom of the unit ( $32 \mathrm{mb}$ b.s.l.), a figurine in terracotta was dated to the 4th-3rd centuries BCE (artefact 15 in Bernal-Casasola et al., 2020a). Between 20.20 and $23.00 \mathrm{~m}$, several ceramics are identified and date to the Roman period (artefacts 2, 3, and 5 in Bernal-Casasola et al., 2020a). This chrono-typological date is confirmed by a radiocarbon-dated seed at 55-215 CE $(1890 \pm 30 \mathrm{BP})$ in the upper part of the unit (20.48 m b.s.l.; Table 1). At 24.00 and $25.15 \mathrm{~m}$ b.s.l., a murex Bolinus brandaris and a murex Hexaplex trunculus are respectively found.

Unit C (20.20 to $6.05 \mathrm{mb}$ b.s.1.) is characterised by a noticeable sedimentation change, i.e. mostly very well-sorted lighter grey sands, together with the absence of artefacts. The first yellow sand layers are observed in this unit too. The sedimentation turns into beige-yellow sands in the upper sequence of VAL-18/Core 2 in Unit D (6.05 to $0.70 \mathrm{~m}$ b.s.l.). Past hydrodynamic conditions seem to have quickly changed within this unit made of medium- to coarse-sand deposits containing some pebbles. Ceramic fragments are found again

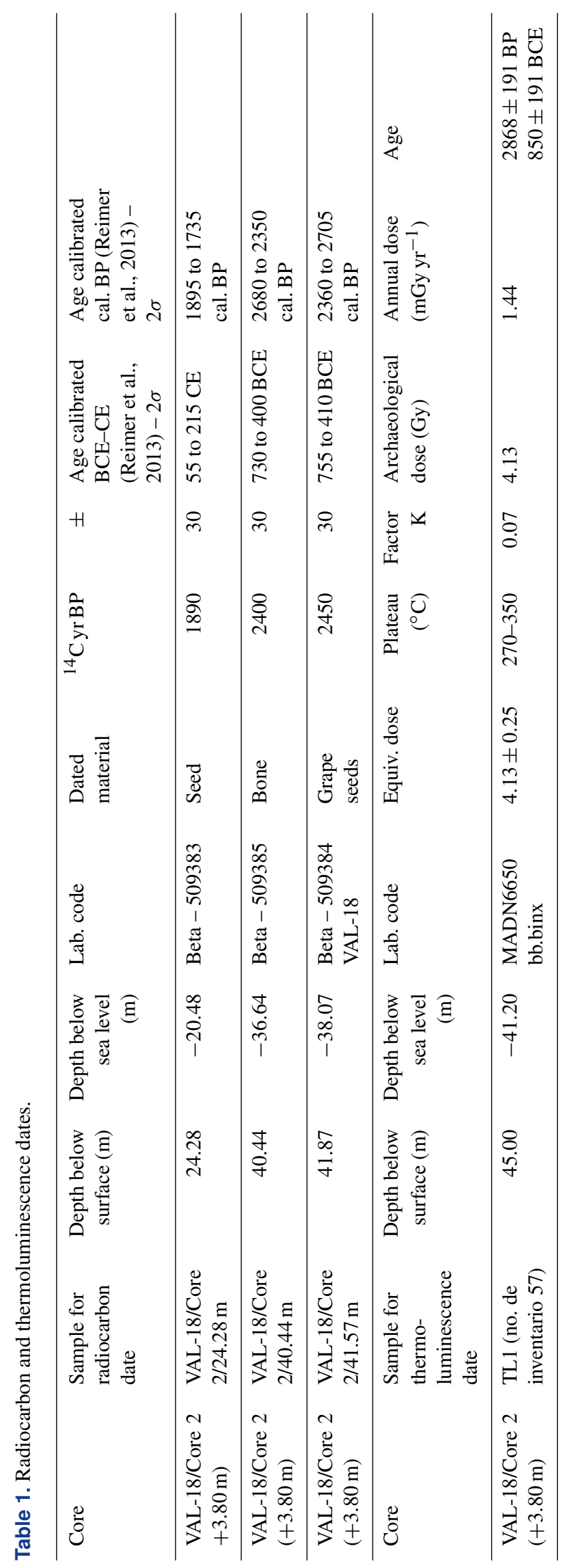


in the upper part of the unit (not identifiable) along with charcoals.

Unit E (0.70 m b.s.l. to $0.80 \mathrm{~m}$ a.s.l), mostly composed of sands embedding pebbles and charcoals, corresponds to a transitional environment between coastal deposits (Unit D) and the uppermost archaeological layers (Unit F). Unit F is composed of heterometric material of anthropic origin. These deposits were excavated and studied using archaeological trenches (Lara Medina et al., 2020).

\subsection{Val-18/Core-3}

This core reaches a depth of $48.00 \mathrm{mb}$ b.s. No dates are available for this core yet. The bottom Unit A (48.00 to $47.30 \mathrm{~m}$ b.s.1.) corresponds to the Plio-Pleistocene conglomerates, upon which the city of Cádiz presently lies.

The first unconsolidated deposit appears in Unit B (47.30 to $43.50 \mathrm{~m}$ b.s.1.). It is composed of very well-sorted, dark grey medium to fine sands (marine environment). Very wellpreserved barnacles are observed at $46.40 \mathrm{~m}$ b.s.1. Barnacles are suspension feeders and mostly inhabit the intertidal zone fixed on the substrate.

Unit C (43.50 to $37.50 \mathrm{~m}$ b.s.1.) is subdivided into six subunits ( $\mathrm{C} 1$ to $\mathrm{C} 6$ ). Sub-unit $\mathrm{C} 1$ suggests a hydrodynamic change with grey silty-clay deposits. Other sub-units express regular alternations from very well-sorted grey sands $(\mathrm{C} 2$, $\mathrm{C} 4$, and C6) to grey silty clay (C3 and C5). Some small pebbles are observed in $\mathrm{C} 6$ too.

Unit D (37.50 to $26.00 \mathrm{~m}$ b.s.1.) is composed of bedded silty clay, sands, and silty sands. Although technical difficulties experienced during the drilling impede a clear identification of the bedding limits, ongoing analyses will hopefully provide a better picture of the shift in the energy controlling the deposition.

Unit E (26.00 to $18.00 \mathrm{~m}$ b.s.1.) is composed of bedded black-grey sands with regularly intercalated $10 \mathrm{~cm}$ thick clay layers. This sedimentation change is coeval with the presence of ceramics, which are not observed in Units B to D.

A sharp limit is observed between Units $\mathrm{E}$ and $\mathrm{F}$ at $18.00 \mathrm{~m}$ b.s.l. Unit F (18.00 to $15.00 \mathrm{~m}$ b.s.1.) is composed of yellow very well-sorted coarse sands $(>1 \mathrm{~mm})$ and small gravels $(>2 \mathrm{~mm})$. Few clayey elements are scarcely distributed and no ceramics are observed in this unit. This coarse deposit can be related to a quick change in the hydrodynamic conditions.

Unit G (15.00 and $6.95 \mathrm{~m}$ b.s.1.) is subdivided into seven sub-units (G1 to G7), which are mostly characterised by alternations between grey sandy silts and silty sands. The coarsest, mostly yellow deposits of G3 and G5 are very well rounded and are similar to the sedimentary facies in Unit F. Unit $\mathrm{H}$ (6.95 to $0.10 \mathrm{~m}$ b.s.1.) is subdivided into four sub-units (H1 to H4) and is composed of well-sorted yellow sands. $\mathrm{H} 1$ is characterised by the coarsest sediments at the bottom, while other subunits show medium to fine sands at the top.
Unit I (0.10 m b.s.l. and $3.00 \mathrm{~m}$ a.s.1.) is composed of heterometric material belonging to the archaeological layers of Cádiz. Excavations on modern archaeological materials located in the Valcárcel building were conducted by Bernal Casasola et al. (2018).

\section{The Bahía-Caleta palaeochannel in Cádiz: a deep palaeogorge?}

Based on the new cores, a maximum depth of the BahíaCaleta palaeochannel around $47 \mathrm{~m}$ below the current sea level was recorded (i.e. the depth at which the contact with the Pliocene-Pleistocene deposits was reached in Val-18/Core3; see Sect. 4.2). Unfortunately, these data cannot be extrapolated to the whole palaeochannel. A cross section in the palaeochannel of Cádiz would be necessary to infer the maximum bathymetry above the Plio-Pleistocene conglomerate. However, a sharp height difference in the underwater topography of the conglomerate is observed. The substratum is located close to the subaerial surface below the shallow archaeological deposits northwards of Val-18/Core-3, and it drops down to $47 \mathrm{~m}$ b.s.l. in the palaeochannel where Val18/Core-3 was drilled. Also, based on the ca. $1 \mathrm{~km}$ long offshore palaeochannel visible to the west of the coring (Fig. 2), its width is estimated between 150 and $250 \mathrm{~m}$. Considering these morphological features (i.e. large height difference combined with the channel width), we suggest that the palaeochannel of Cádiz may represent a palaeogorge. Interestingly, very well-sorted marine sands are deposited directly over the Plio-Pleistocene substratum in VAL-18/Core3 (Unit B). No fluvial deposits are observed. A marine origin of these sediments is confirmed by the occurrence of wellpreserved barnacles (currently processed for a ${ }^{14} \mathrm{C}$ dating) at $46.40 \mathrm{~m}$ b.s.l. If the fluvial origin of the palaeogorge can hardly be questioned, the presence of fluvial deposits in other areas of the palaeogorge may be expected.

This palaeogorge can be tracked to the west using highresolution bathymetry proposed by Higueras-Milena Castellano and Sáez Romero (2014) and reported in Fig. 2. This topographical survey clearly shows that the palaeochannel was flowing northwards after passing through the area of Cádiz. This is confirmed by a geophysical survey, where geopulse seismic data exhibit an identical offshore bathymetry westwards of our corings (northward orientation of the palaeogorge, Fig. 2; Llave et al., 1999). As for its origin, two main hypotheses were suggested. First, the currently underwater gorge might be related to a palaeocourse of the Guadalete River (Dabrio et al., 2000; Wolf et al., 2014) or secondly to the Guadalquivir River (Chic García, 1979; Gracia and Benavente, 2000; Arteaga Matute and Roos, 2002). As for its age, it has been suggested that given the different palaeogeography of the Bay of Cádiz during the marine lowstand associated with the LGM, generalised fluvial incision might have occurred at that time in this area (Hernández 
Molina et al., 1996). Future results obtained in the framework of this project will provide new insights into these unanswered questions.

\section{Late Holocene coastal dynamics and preliminary results}

\subsection{A fast coastal sedimentation rate inferred from VAL-18/Cores 2 and 3}

The dated VAL-18/Core 2 reveals an important sedimentation rate over more than $20 \mathrm{~m}$. Over the entirety of Units A and B (41.2 to $20.2 \mathrm{mb}$ b.s.l.), the sedimentation rate is estimated between 1.6 and $2.8 \mathrm{~cm} \mathrm{yr}^{-1}$. The time range of this sedimentation starts at least from the beginning of the 1st millennium BCE and ends after the beginning of the 1st millennium CE. This is concomitant with the Phoenician origins of the city and includes the development of Cádiz during the Roman period, when Cádiz was one of the major ports of the western Mediterranean.

The interpretation of the high sedimentation rate, possibly lasting over 1 millennium, will be a key question to future research. It probably results from a combination of local factors, related to the waste of the ancient city of Cádiz, and regional factors, related to the progradation of the river mouth of the Guadalete, or else to sediment trapped during tsunami/storm events. Additionally, these local and regional considerations will take into account possible anthropic impacts within the Guadalete River watershed as well as global palaeoclimatic drivers.

Some authors have already argued that waste from the city could have contributed to the filling of the palaeochannel (Ramírez Delgado, 1982). The high content of archaeological material (e.g. Unit B of VAL-18/Core 2) points to this hypothesis, but this must be completed by complementary and systematic analyses. The $>45 \mathrm{~m}$ thick sedimentary archives of the 3 millennium long history of Cádiz are also to be compared with the $7 \mathrm{~m}$ thick sequence related to the history of Cádiz studied in the "Testaccio haliéutico de Gades" (Bernal Casasola et al., 2019a). This garbage mount was recently excavated close to the cores drilled in the Bahía-Caleta palaeochannel (Bernal Casasola et al., 2019a). Debris could have been transported into the palaeochannel either naturally or anthropogenically.

\subsection{High-energy events from the sea: palaeostorms and palaeotsunamis}

The palaeochannel of Cádiz corresponds to an offshore sedimentation trap for high-energy events such as palaeostorms and palaeotsunamis. Yellow coarse sand layers observed in the upper sequences of Cores 2 and 3 will be thoroughly investigated and dated. The difference between yellow-beige deposits in the upper $10 \mathrm{~m}$ (Unit D in VAL-18/Core 2 and Unit H in VAL-18/Core 3) and the dark grey deposits below this limit is most probably due to local factors. This limit at ca. $10 \mathrm{~m}$ b.s.l. is probably the fair-weather wave base. However, the coarse-grained yellow-beige layers observed below $10 \mathrm{~m}$ in VAL-18/Core 2/Unit C and VAL-18/Core 3/Unit G and $\mathrm{F}$ are most probably related to regional events, possibly storms or tsunamis.

These high-energy events will contribute to the reconstruction of the history of the coastal hazards of this littoral area (Lario et al., 2010, 2011; Ruiz et al., 2013). Whilst the spit of Cádiz and the palaeo-islands are exposed to storms (Benavente et al., 2006; Del Río et al., 2012), palaeotsunami occurrences are evidenced in various depositional settings in and around the Bay of Cádiz. This includes lithofacies recording high-energy events in offshore sediments (Gutiérrez-Mas et al., 2009a), washover fans on the Valdelagrana spit (Luque et al., 2002), and coarse-grained shelly layers intercalated in the marshlands of the Guadalete/San Pedro River (Dabrio et al., 1997; Luque et al., 2002; de Duque, 2008; Gutiérrez-Mas, 1992, 2011; Gutiérrez-Mas et al., 2009b). The Lisbon tsunami of $1755 \mathrm{CE}$ was the focus of much research in this context (Dabrio et al., 1997; Cuven et al., 2013; Font et al., 2013).

\section{Future research perspectives}

The palaeogeographical considerations listed above will be considered in regard to new analyses in process (e.g. sedimentological data, bioindicator identification, and absolute dating). Three main research topics will be explored.

\subsection{Palaeogeography}

Palaeogeographical and palaeotopographical reconstructions will be proposed for the infill of the palaeogorge in relation to regional palaeoclimatic data, sea-level evolution, and sediment input from the watershed. Ultimately, we will discuss the interconnection of the Cádiz archipelago during the Phoenician-Punic and Roman periods. A more robust chronology of the stratigraphic sequences will be proposed with additional OSL and radiocarbon dates, along with palaeoenvironmental analysis (e.g. grain size, mineralogy, organic and inorganic geochemistry, ostracod, foraminifera, and pollen analysis).

\subsection{Urban geoarchaeology}

The impact of the city through time will also be explored based on the analysis of the high-resolution sedimentary sequences. Based on new dates, geochemical analyses (e.g. ICP-MS and GC-MS analyses, especially looking at lead pollution), pollen analyses, plant macroremains, and charcoals, our research group will characterise the origins of the settlement, the resilience of the city against coastal hazards, the evolution of the urban impacts, the possible productions 
in the city, the evolution of the vegetal landscape, and the palaeopollution records.

\subsection{Palaeoeconomy}

Finally, new information related to the palaeoeconomy of the city of Cádiz will be proposed (e.g. plant macroremains, charcoals, pollens, malacofauna, organic and inorganic geochemistry). Notably, we will look at the introduction of some cultivated plants, the development of vineyards and olive trees, or Murex exploitation during the Phoenician-Punic and Roman periods. A first date obtained from radiocarbon dating of a grape seed in VAL-18/Core3 (755-410 BCE) may confirm observations made in Spain (Buxó, 2008; PérezJordà et al., 2017) and locally in the Bay of Cádiz at Castillo de Doña Blanca (Chamorro, 1994). Important wine production is confirmed in the 8th-7th centuries BCE in this archaeological site (Chamorro, 1994). Complementary and systematic analyses will shed new light on commercial activity in Cádiz.

Data availability. Preliminary data outlined in this report are not publicly available as analyses are still in progress.

Author contributions. FS, DBC, JJD, and ML designed the research. FS, DBC, JJD, ML, SDB, DE, PW, PA, PS, LH, CV, SC, HD, LSc, FP, MT, AM, CV, LSa, JM, PVM, VR, BK, ASB, JML, and GR performed the research. FS, DBC, JJD, ML, and MT analysed the data. FS, DBC, JJD, ML, SDB, PA, PS, HD, LSc, FP, and GR wrote the paper.

Competing interests. The authors declare that they have no conflict of interest.

Acknowledgements. We thank the University of Cádiz, which financed the archaeological works, especially the Vice-Director, José María Mariscal Chicano, and Andrés Agudo Martínez, Director of the Infrastructures Area. We are also grateful to María Rotllán, geologist of the Control de Calidad Cádiz company. Jacob Morales is a beneficiary of a Ramón y Cajal research contract funded by the Ministry of Science, Innovation and Universities (RYC-2015-18072) of the Government of Spain. Paloma Vidal Matutano is a beneficiary of a Juan de la Cierva - Formación fellowship, funded by the Ministry of Science, Innovation and Universities (FJCI-2017-32461). Archaeobotanical identifications have been made in the archaeology laboratory of the Department of Historical Sciences of the University of Las Palmas de Gran Canaria. Part of the mineralogical analysis was carried out in the laboratory of the Geoarchaeological and Archaeometric Unit (UGEA-PHAM) and the SCiCYT of the University of Cádiz. We thank Ana Durante Macías and Juan de Dios Barambio for their help in the sample processing, Leah Holguin for proofreading the English text, and the reviewers.
Financial support. This research has been supported by the Government of Spain/FEDER (grant no. HAR2016-78691-P), SACEIMAR of the CEIMAR Excellence Campus (University of Cádiz), ARQUEOSTRA and ARQUEOFISH (P18-FR-1483) of the Junta de Andalucía, "Retracer la paléotopographie et l'histoire de Cadix à travers ses archives sédimentaires - PalaeoCADIX-Y-Z" under the framework of the IdEx Unistra (Université de Strasbourg) supported by the Investments for the Future programme of the French Government (grant no. CF/EK/FF/ACS/N²019-250) and PhéniCane funded by the CNRS (MITI-PEPS ECOMOB).

Review statement. This paper was edited by Ulrich Harms and reviewed by Roberta Pini and one anonymous referee.

\section{References}

Alonso Villalobos, C., Gracia Prieto, F. J., and Ménanteau, L.: Las salinas de la Bahía de Cádiz durante la Antigüedad: visión geoarqueológica de un problema histórico, Spal. Revista de Prehistoria y Arqueología, 12, 317-332, 2003.

Arteaga, O. and Roos, H. D. S. y A.-M.: Geoarqueología dialéctica en la Bahía de Cádiz, Rev. Atlántica-Mediterránea Prehist. Arqueol. Soc., 1, 21-116, 2008.

Arteaga, O., Kölling, A., Kölling, M., Roos, A.-M., Schulz, H., and Schulz, H. D.: El puerto de Gadir. Investigación geoarqueológica en el casco antiguo de Cádiz, Rev. Atlántica-Mediterránea Prehist. Arqueol. Soc., 4, 345-416, 2001.

Arteaga Matute, O. and Roos, A.-M.: El puerto fenicio-púnico de Gadir: una nueva visión desde la geoarqueología urbana de Cádiz, Spal, 11, 21-39, 2002.

Baena Pérez, J., Zazo, C., and Goy, J. L.: Mapa Geológico de España. E. 1 : 50000 - Hoja 1061 (11-45) - Cádiz, Instituto Geológico y Minero de España (IGME), Madrid, Spain, 1984.

Borja Barrera, F., Gutiérrez Mas, J. M., and del Olmo, F. D.: Fases de dunas durante el Holoceno reciente en el litoral de El Puerto de Santa María (Cádiz), Geogaceta, 21, 39-42, 1997.

Benavente, J., Del Río, L., Gracia, F. J., and Martínez-delPozo, J. A.: Coastal flooding hazard related to storms and coastal evolution in Valdelagrana spit (Cadiz Bay Natural Park, SW Spain), Cont. Shelf Res., 26, 1061-1076, https://doi.org/10.1016/j.csr.2005.12.015, 2006.

Bendala Galán, M.: Cádiz: la ciudad antigua, in: Actas del Congreso Internacional "El Estrecho de Gibraltar", 16-19 November 1987, Ceuta, Madrid, Spain, vol. I, 55-70, 1988.

Bernal Casasola, D.: El puerto romano de Gades. Novedades arqueológicas, in Rome, Portus and the Mediterranean, British School at Rome, London, UK, 225-244, 2012.

Bernal Casasola, D. B.: Gades y su bahía en la Antigüedad. Reflexiones geoarqueológicas y asignaturas pendientes, Rev. AtlánticaMediterránea Prehist. Arqueol. Soc., 1, 267-308, 2008.

Bernal Casasola, D., Díaz Rodrígue, J. J., and Lara Medina, M.: Adelanto del Diagnóstico Arqueológico de la Actividad Arqueológica Preventiva en el Edificio Valcárcel (Cádiz), Universidad de Cádiz, Cádiz, Spain, 2018.

Bernal Casasola, D., Vargas Girón, J. M., and Lara Medina, M.: 7 metros de la Historia de Cádiz: Arqueología en El Olivillo y 
en el Colegio Mayor Universitario, Universidad de Cádiz, Cádiz, Spain, 2019.

Bernal-Casasola, D., Salomon, F., Díaz, J. J., Lara Medina, M., Rixhon, G., Morales-Mateos, J. B., and Vidal Matutano, P.: Deeper than expected: The finding of a remarkable ancient harbour at Gadir/Gades and an exceptional sedimentary archive (Cadiz, Southern Spain), International Journal of Nautical Archaeology, accepted, 2020a.

Bernal-Casasola, D., Salomon, F., Díaz, J. J., Lara Medina, M., and Rixhon, G.: Un cambio de paradigma paleotopográfico en GadirGades. Geoarqueología de profundidad en en su estrecho interinsular (Canal Bahía-Caleta), Archivo Español de Arqueología, accepted, 2020b.

Botto, M.: Los Fenicios en la Bahía de Cádiz: nuevas investigaciones, Fabrizio Serra editore, Pisa-Roma, Italy, 2014.

Buforn, E., Udías, A., and Colombás, M. A.: Seismicity, source mechanisms and tectonics of the Azores-Gibraltar plate boundary, Tectonophysics, 152, 89-118, https://doi.org/10.1016/00401951(88)90031-5, 1988.

Buxó, R.: The agricultural consequences of colonial contacts on the Iberian Peninsula in the first millennium b.c, Veg. Hist. Archaeobot., 17, 145-154, https://doi.org/10.1007/s00334-0070133-7, 2008.

Carayon, N.: Note sur l'organisation spatiale des agglomérations insulaires phéniciennes et puniques, Méditerranée Rev. Géographique Pays Méditerranéens, J. Mediterr. Geogr., 117, 111114, https://doi.org/10.4000/mediterranee.6020, 2011.

Chamorro, J. G.: Flotation strategy: Method and sampling plant dietary resources of Tartessian times at Doña Blanca, in Castillo de Doña Blanca: Archaeo-environmental investigations in the Bay of Cádiz, Spain (750-500 BC), BAR International Series, Oxford, UK, vol. 593, 21-35, 1994.

Chic García, G.: Gades y la desembocadura del Guadalquivir, Gades, 3, 7-23, 1979.

Corzo Sánchez, R.: Paleotopografía de la bahía gaditana, Gades, 5, 5-14, 1980.

Cuven, S., Paris, R., Falvard, S., Miot-Noirault, E., Benbakkar, M., Schneider, J.-L., and Billy, I.: High-resolution analysis of a tsunami deposit: Case-study from the 1755 Lisbon tsunami in southwestern Spain, Mar. Geol., 337, 98-111, https://doi.org/10.1016/j.margeo.2013.02.002, 2013.

Dabrio, C. J., Goy, J. L., Lario, J., Zazo, C., Borja, F., and González, A.: The Guadalete estuary during the holocene times (Bay of Cadiz, Spain), Mediterr. Black Sea Shorel. INQUA Newsl., 17, 19-22, 1995.

Dabrio, C. J., Goy, J. L., and Zazo, C.: The record of the tsunami produced by the 1755 Lisbon earthquake in Valdelagrana spit (Gulf of Cádiz, southern Spain), available at: http://rabida.uhu. es/dspace/handle/10272/10472 (last access: 17 May 2019), 1997.

Dabrio, C. J., Zazo, C., Lario, J., Goy, J. L., Sierro, F. J., Borja, F., González, J. Á., and Flores, J. A.: Sequence stratigraphy of Holocene incised-valley fills and coastal evolution in the Gulf of Cádiz (southern Spain), Geol. En. Mijnb., 77, 263-281, https://doi.org/10.1023/A:1003643006015, 1998.

Dabrio, C. J., Zazo, C., Goy, J. L., Sierro, F. J., Borja, F., Lario, J., Gonzalez, J. A., and Flores, J. A.: Depositional history of estuarine infill during the last postglacial transgression (Gulf of Cadiz, Southern Spain), Mar. Geol., 162, 381-404, 2000. de Duque, L.: El impacto de eventos catastróficos costeros en el litoral del Golfo de Cádiz, Rev. Atlántica-Mediterránea Prehist. Arqueol. Soc., 1, 131-153, 2008.

Del Río, L., Plomaritis, T. A., Benavente, J., Valladares, M., and Ribera, P.: Establishing storm thresholds for the Spanish Gulf of Cádiz coast, Geomorphology, 143-144, 13-23, https://doi.org/10.1016/j.geomorph.2011.04.048, 2012.

Domínguez-Bella, S.: Geología en el entorno de la ciudad de Cádiz, Rev. Atlántica-Mediterránea Prehist. Arqueol. Soc., 1, 117-130, 2008.

Domínguez Monedero, A.: Gadir, in Mito y Arqueología en el nacimiento de las ciudades legendarias en la Antigüedad, Universidad de Sevilla, Sevilla, Spain, 153-197, 2012.

Font, E., Veiga-Pires, C., Pozo, M., Nave, S., Costas, S., Ruiz Muñoz, F., Abad, M., Simões, N., Duarte, S., and RodríguezVidal, J.: Benchmarks and sediment source(s) of the 1755 Lisbon tsunami deposit at Boca do Rio Estuary, Mar. Geol., 343, 1-14, https://doi.org/10.1016/j.margeo.2013.06.008, 2013.

Fresnadillo García, R., Tabales Rodrígues, M. A., Maya Torcelly, R., Jurado Fresnadillo, G., and Pajuelo Saez, J. M.: Cádiz en la Edad Media, Rev. Atlántica-Mediterránea Prehist. Arqueol. Soc., 1, 399-411, 2008.

Gómez Ponce, C., Borja, F., Lagostena, L., López Amador, J., Ruiz, J., and Borja, C.: Primeras fases de la evolución de la flecha litoral de Valdelagrana (El Puerto de Santa María, Cádiz). Datos arqueológicos, in: Cuaternario Ibérico, Universidad de Huelva, Huelva, Spain, 165-167, 1997.

Goy, J., Zazo, C., Dabrio, C. J., Lario, J., Borja, F., Sierro, F. J., and Flores, J.: Global and regional factors controlling changes of coastlines in southern Iberia (Spain) during the Holocene, Quaternary Sci. Rev., 15, 773-780, 1996.

Gracia, F. J. and Benavente, J.: Geomorfología de la costa atlántica gaditana, in: Geomorfología litoral, Procesos activos, edited by: De Andrés, J. R. and Gracia, F. J., SEG. ITGE. Servicios de Publicaciones Universidad de Cadiz, Madrid, Spain, 7, 237-254, 2000.

Gracia, F. J., Rodríguez-Vidal, J., Cáceres, L. M., Belluomini, G., Benavente, J., and Alonso, C.: Diapiric uplift of an MIS 3 marine deposit in SW Spain: Implications for Late Pleistocene sea level reconstruction and palaeogeography of the Strait of Gibraltar, Quaternary Sci. Rev., 27, 2219-2231, https://doi.org/10.1016/j.quascirev.2008.08.013, 2008.

Gutiérrez-Mas, J. M.: Estudio de los sedimentos recientes de la plataforma continental y Bahía de Cádiz, PhD Thesis, Universidad de Cádiz, Cádiz, Spain, 1992.

Gutiérrez Mas, J. M.: Glycymeris shell accumulations as indicators of recent sea-level changes and high-energy events in Cadiz Bay (SW Spain), Estuar. Coast. Shelf Sci., 92, 546-554, https://doi.org/10.1016/j.ecss.2011.02.010, 2011.

Gutiérrez Mas, J. M., Martin Algarra, A., Domínguez-Bella, S., and Moral Cardona, J. P.: Introducción a la geología de la provincia de Cádiz, Servicio de Publicaciones, Universidad de Cádiz, Cádiz, Spain, 1991.

Gutiérrez Mas, J. M., Hernández-Molina, F. J., and López-Aguayo, F.: Holocene sedimentary dynamics on the Iberian continental shelf of the Gulf of Cádiz (SW Spain), Cont. Shelf Res., 16, 1635-1653, https://doi.org/10.1016/0278-4343(96)00010-6, 1996. 
Gutiérrez-Mas, J. M., López-Arroyo, J., and Morales, J. A.: Recent marine lithofacies in Cadiz Bay (SW Spain): Sequences, processes and control factors, Sediment. Geol., 218, 31-47, https://doi.org/10.1016/j.sedgeo.2009.04.002, 2009a.

Gutiérrez-Mas, J. M., Juan, C., and Morales, J. A.: Evidence of high-energy events in shelly layers interbedded in coastal Holocene sands in Cadiz Bay (south-west Spain), Earth Surf. Process. Land., 34, 810-823, https://doi.org/10.1002/esp.1770, 2009b.

Hernández Molina, F. J., Fernández Puga, M. C., Fernández Salas, L. M., Llave, E., Lobo, F. J., Vázquez Garrido, J. T., Acosta, J., and López Aguayo, F.: Distribución y estructuración sedimentaria de los depósitos del Holoceno Terminal en la Bahía de Cádiz, Geogaceta, 20, 424-427, 1996.

Higueras-Milena Castellano, A. and Sáez Romero, A. M.: Aplicación experimental de técnicas geofísicas para la localización, investigación y difusión del patrimonio arqueológico en la zona de La Caleta (Cádiz), in: Arqueología subacuática española: Actas del I Congreso de Arqueología Naútica y Subacuática Española, 14-16 March 2013, Cartagena, Colombia, UCA Editores, 275-286, 2014.

Iriarte-Chiapusso, M. J., Ocete-Pérez, C. A., Hernández-Beloqui, B., and Ocete-Rubio, R.: Vitis vinifera in the Iberian Peninsula: A review, Plant Biosyst.-Int. J. Deal. Asp. Plant Biol., 151, 245257, https://doi.org/10.1080/11263504.2016.1165751, 2017.

Lara Medina, M.: Urbs iulia gaditana. El urbanismo de gades a través de su registro arqueológico. Análisis y propuesta interpretativa, Universidad de Cádiz, available at: https://dialnet.unirioja. es/servlet/tesis?codigo=60944 (last access: 9 December 2018), 2016.

Lara Medina, M.: Gades y la problemática del canal "BahíaCaleta", Novedas desde la arqueología, Universidad de, Cádiz, Spain, 417-419, 2018.

Lara Medina, M., Bernal-Casasola, D., and Díaz Rodríguez, J. J.: Resultados de la Actividad Arqueológica Preventiva realizada en el Edificio Valcárcel, Anu. Arqueol. Andal., in press, 2020.

Lario, J., Zazo, C., Dabrio, C. J., Somoza, L., Goy, J. L., Bardají, T., and Silva, P. G.: Record of recent Holocene sediment input on spit bars and deltas of South Spain, J. Coast. Res., 17, 241-245, 1995.

Lario, J., Zazo, C., Goy, J. L., Dabrio, C. J., Borja, F., Silva, P. G., Sierro, F., González, A., Soler, V., and Y1l, E.: Changes in sedimentation trends in SW Iberia Holocene estuaries (Spain), Quatern. Int., 93-94, 171-176, https://doi.org/10.1016/S10406182(02)00015-0, 2002.

Lario, J., Luque, L., Zazo, C., Goy, J. L., Spencer, C., Cabero, A., Bardají, T., Borja, F., Dabrio, C. J., Civis, J., GonzálezDelgado, J. Á., Borja, C., and Alonso-Azcárate, J.: Tsunami vs. storm surge deposits: a review of the sedimentological and geomorphological records of extreme wave events (EWE) during the Holocene in the Gulf of Cadiz, Spain, Z. Gemorphol. Suppl. Issues, 54, 301-316, https://doi.org/10.1127/03728854/2010/0054S3-0029, 2010.

Lario, J., Zazo, C., Goy, J. L., Silva, P. G., Bardaji, T., Cabero, A., and Dabrio, C. J.: Holocene palaeotsunami catalogue of SW Iberia, Quatern. Int., 242, 196-200, https://doi.org/10.1016/j.quaint.2011.01.036, 2011.

Llave, E., Hernández Molina, F. J., Alonso, C., Gallardo, M., Vázquez Garrido, J. T., and López Aguayo, F.: Caracterización y evolución del paleocauce del río Guadalete en la Bahía de Cádiz durante el Cuaternario terminal, Geogaceta, 26, 43-46, 1999.

Lobo, F. J., Fernández-Salas, L. M., Hernández-Molina, F. J., González, R., Dias, J. M. A., del Río, V. D., and Somoza, L.: Holocene highstand deposits in the Gulf of Cadiz, SW Iberian Peninsula: A high-resolution record of hierarchical environmental changes, Mar. Geol., 219, 109-131, https://doi.org/10.1016/j.margeo.2005.06.005, 2005.

Luque, L., Lario, J., Civis, J., Silva, P. G., Zazo, C., Goy, J. L., and Dabrio, C. J.: Sedimentary record of a tsunami during Roman times, Bay of Cadiz, Spain, J. Quaternary Sci., 17, 623-631, https://doi.org/10.1002/jqs.711, 2002.

MacPherson, J.: Bosquejo geológico de la provincial de Čádiz: Por J. Mac-Pherson, Imprenta de la revista medica, Carlos BaillyBailliere, Madrid, Spain, 1873.

Márquez Carmona, L. and Alonso Villalobos, C.: El sistema portuario de la bahía de Cádiz en época moderna a través de la cartografía histórica, in: Fronteras de agua: las ciudades portuarias y su universo cultural (s. XIV-XXI), edited by: Reyez-García Hurtado, M. and Rey Castelao, O., Universidade de Santiago e Compostela press, Santiago de Compostela, Spain, 181-195, 2016.

Moral Cardona, J. P.: Estudio de las arenas de la cuenca del río Guadalete y zonas próximas, $\mathrm{PhD}$ Thesis, Universidad de Cádiz, Cádiz, Spain, 1994.

Moral Cardona, J. P., Achab, M., Domínguez Bella, S., Gutiérrez Mas, J. M., Morata Céspedes, D., and Parrado Román, J. M.: Estudio comparativo de los minerales de la fracción pesada en los sedimentos de las terrazas del Río Guadalete y fondos de la Bahía de Cádiz, available at: http://rabida.uhu.es/dspace/handle/ 10272/13198 (last access: 6 September 2019), 1996.

O'Flanagan, P.: Port Cities of Atlantic Iberia, c. 1500-1900, Routledge, London, UK, 2016.

Pérez-Jordà, G., Peña-Chocarro, L., García Fernández, M., and Vera Rodríguez, J. C.: The beginnings of fruit tree cultivation in the Iberian Peninsula: plant remains from the city of Huelva (southern Spain), Veg. Hist. Archaeobot., 26, 527-538, https://doi.org/10.1007/s00334-017-0610-6, 2017.

Pliny: Historiae Naturae/Natural History, Bks. 3-7, v.2, translated by: Rackham, H., Loeb Classical Library, Harvard University Press, Cambridge, UK, 1942.

Ponce Cordones, F.: Consideraciones en torno a la ubicación del Cádiz fenicio, An. Univ. Cádiz, II, 99-121, 1985.

Ramírez Delgado, J. R.: Los primitivos núcleos de asentamiento en la ciudad de Cádiz, Excmo. Ayuntamiento de Cádiz, Cádiz, Spain, 1982.

Reed, J. M., Stevenson, A. C., and Juggins, S.: A multiproxy record of Holocene climatic change in southwestern Spain: the Laguna de Medina, Cádiz, Holocene, 11, 707-719, https://doi.org/10.1191/09596830195735, 2001.

Reimer, P. J., Bard, E., Bayliss, A., Beck, J. W., Blackwell, P. G., Bronk Ramsey, C., Buck, C. E., Cheng, H., Edwards, R. L., Friedrich, M., Grootes, P. M., Guilderson, T. P., Haflidason, H., Hajdas, I., Hatté, C., Heaton, T. J., Hoffmann, D. L., Hogg, A. G., Hughen, K. A., Kaiser, K. F., Kromer, B., Manning, S. W., Niu, M., Reimer, R. W., Richards, D. A., Scott, E. M., Southon, J. R., Staff, R. A., Turney, C. S. M., and van der Plicht, J.: IntCal13 and Marine13 radiocarbon age calibration curves 0-50 000 years cal BP, Radiocarbon, 55, 1869-1887, 2013. 
Rodríguez-Polo, S., Gracia, F. J., Benavente, J., and Río, L. D.: Geometry and Recent Evolution of the Holocene Beach Ridges of the Valdelagrana Littoral Spit (Cádiz Bay, SW Spain), J. Coast. Res., 56, 20-23, 2009.

Ruiz, F., Rodríguez-Vidal, J., Abad, M., Cáceres, L. M., Carretero, M. I., Pozo, M., Rodríguez-Llanes, J. M., GómezToscano, F., Izquierdo, T., Font, E., and Toscano, A.: Sedimentological and geomorphological imprints of Holocene tsunamis in southwestern Spain: An approach to establish the recurrence period, Geomorphology, 203, 97-104, https://doi.org/10.1016/j.geomorph.2013.09.008, 2013.

Strabo: Geography, Books 3-5, v.2, translated by: Leonard Jones, H., Loeb Classical Library, Harvard University Press, Cambridge, UK, 1923.

Vázquez, J. T., Llave, E., Molina, F. J. H., and Aguayo, F. L.: Principales rasgos tectónicos de la Bahía de Cádiz durante el $\mathrm{Cu}$ aternario terminal, in: V Congreso Geológico de España, 1014 July 2000, Alicante, Spain, Servicio de Publicaciones, 239242, 2000.

Wolf, D. and Faust, D.: Western Mediterranean environmental changes: evidences from fluvial archives, Quaternay Sci. Rev., 122, 30-50, 2015.
Wolf, D., Seim, A., and Faust, D.: Fluvial system response to external forcing and human impact - Late Pleistocene and Holocene fluvial dynamics of the lower Guadalete River in western Andalucía (Spain), Boreas, 43, 422-449, https://doi.org/10.1111/bor.12044, 2014.

Zazo, C., Goy, J. L., Somoza, L., Dabrio, C. J., Belluomini, G., Improta, S., Lario, J., Bardaji, T., and Silva, P. G.: Holocene Sequence of Sea-Level Fluctuations in Relation to Climatic Trends in the Atlantic-Mediterranean Linkage Coast, J. Coast. Res., vol. 10, available at: http://journals.fcla.edu/jcr/article/ view/79464 (last access: 13 November 2014), 1994.

Zazo, C., Goy, J. L., Lario, J., and Silva, P. G.: Littoral zone and rapid climatic changes during the last 20000 years. The Iberia study case, Z. Geomorphol. Suppl., 102, 119-134, 1996.

Zazo, C., Silva, P. G., Goy, J. L., Hillaire-Marcel, C., Ghaleb, B., Lario, J., Bardajı̀̀, T., and González, A.: Coastal uplift in continental collision plate boundaries: data from the Last Interglacial marine terraces of the Gibraltar Strait area (south Spain), Tectonophysics, 301, 95-109, https://doi.org/10.1016/S00401951(98)00217-0, 1999. 